\title{
Article \\ Morphology and Crystallography Analyses of HSLA Steels with Hardenability Enhanced by Tailored C-Ni Collocation
}

\author{
Zhipeng Liu ${ }^{1, \dagger}$, Yishuang Yu ${ }^{1,+}{ }^{+}$, Jie Yang ${ }^{1}$, Zhiquan Wang ${ }^{1}$, Hui Guo ${ }^{1,2,3, *}$ and Chengjia Shang ${ }^{1,2,3}$ \\ 1 Collaborative Innovation Center of Steel Technology, University of Science and Technology Beijing, \\ Beijing 100083, China; g20209284@xs.ustb.edu.cn (Z.L.); yuysh@hotmail.com (Y.Y.); \\ yj13146000399@163.com (J.Y.); b20180500@xs.ustb.edu.cn (Z.W.); cjshang@ustb.edu.cn (C.S.) \\ 2 Yantai Institute of Industrial Technology, University of Science and Technology Beijing, Yantai 264003, China \\ 3 Yangjiang Branch, Guangdong Laboratory for Materials Science and Technology (Yangiiang Advanced Alloys \\ Laboratory), Yangiiang 529500, China \\ * Correspondence: guohui@mater.ustb.edu.cn \\ + First authors.
}

check for updates

Citation: Liu, Z.; Yu, Y.; Yang, J.; Wang, Z.; Guo, H.; Shang, C. Morphology and Crystallography Analyses of HSLA Steels with Hardenability Enhanced by Tailored C-Ni Collocation. Metals 2022, 12, 32. https://doi.org/10.3390/met12010032 Academic Editor: Ricardo Branco

Received: 2 December 2021 Accepted: 21 December 2021 Published: 24 December 2021

Publisher's Note: MDPI stays neutral with regard to jurisdictional claims in published maps and institutional affiliations.

Copyright: (c) 2021 by the authors. Licensee MDPI, Basel, Switzerland. This article is an open access article distributed under the terms and conditions of the Creative Commons Attribution (CC BY) license (https:// creativecommons.org/licenses/by/ $4.0 /)$.

\begin{abstract}
High hardenability is of great importance to ultra-heavy steel plates and can be achieved by tailoring the composition of steel. In this study, the continuous cooling transformation (CCT) curves of two high-strength low-alloy (HSLA) steels (0.16C-0.92Ni steel and $0.12 \mathrm{C}-1.86 \mathrm{Ni}$ steel) were elucidated to reveal the significance of $\mathrm{C}-\mathrm{Ni}$ collocation on hardenability from the perspective of morphology and crystallography. At a low cooling rate $\left(0.5^{\circ} \mathrm{C} / \mathrm{s}\right)$, the $0.12 \mathrm{C}-1.86 \mathrm{Ni}$ steel showed higher microhardness than $0.16 \mathrm{C}-0.92 \mathrm{Ni}$ steel. The microstructure in $0.16 \mathrm{C}-0.92 \mathrm{Ni}$ steel was mainly granular bainite with block-shaped martensite/austenite islands (M/A islands), while that in $0.12 \mathrm{C}$ $1.86 \mathrm{Ni}$ steel was typically lath bainite with film-shaped $\mathrm{M} / \mathrm{A}$ islands, denoting that the $0.12 \mathrm{C}-1.86 \mathrm{Ni}$ steel is of higher hardenability. Moreover, the $0.12 \mathrm{C}-1.86 \mathrm{Ni}$ steel exhibited a higher density of block boundaries, especially V1/V2 boundaries. The higher density of block boundaries resulted from the weakened variant selection due to the larger transformation driving force and more selfaccommodation of transformation strain induced by the reduced carbon and increased nickel content.
\end{abstract}

Keywords: high-strength low-alloy steel; hardenability; bainite; grain boundaries; variant pairing; phase transformation

\section{Introduction}

For conventional high-strength low-alloy ultra-heavy plates, a matrix structure with sufficiently high strength, such as lath martensite/bainite is obtained by quenching, which is subsequently tempered to improve toughness [1-4]. However, it is usually impossible to avoid the low cooling rate in the center of the ultra-heavy plates during cooling, causing inhomogeneous microstructure and mechanical properties across the thickness direction, which highlights the need to enhance the hardenability of the alloy [5-7]. Granular bainite/ferrites may be formed at lower cooling rates in the center of the plates with low hardenability $[8,9]$. On one side, this leads to the existence of incompletely transformed martensite-austenite islands (M/A islands), which are often a factor in launching cracks, and on the other side, there are fewer high-angle grain boundaries (HAGBs) to impede crack propagation effectively $[10,11]$. How to improve the hardenability of low-alloy steel to obtain a high-strength matrix structure at low cooling rates in the center of the ultra-heavy plates is the focus of this study.

A convenient way to improve the hardenability of low-alloy steels is through increasing the concentration of carbon and alloying elements [12-16]. Generally, carbon is the element most commonly used to improve hardenability, and the hardenability of alloy steels increases with increasing carbon content $(<0.77 \mathrm{wt}$. \%) [17]. However, the dramatic loss in toughness and weldability associating with increasing carbon content limits its use in the enhancement of hardenability $[18,19]$. Nickel (Ni) is an element that 
can improve hardenability, which is also usually added to the heavy plates to improve the toughness $[20,21]$. To ensure hardenability without a significant decrease in toughness and weldability, we attempted to reduce the carbon content whilst increasing the Ni to improve the hardenability. In this study, the effect of different C-Ni combinations on the phase products and hardenability of two HSLA steels from the perspective of morphology and crystallography was elucidated to clarify the mechanism of C-Ni collocation that improves the hardenability.

\section{Materials and Methods}

The chemical composition of the two experimental steels used in the present work is listed in Table 1. Alloys were melted in a $25 \mathrm{~kg}$ vacuum induction furnace and rolled into thick plates with a thickness of $50 \mathrm{~mm}$. Cylindrical samples of $10 \mathrm{~mm}$ in length and $4 \mathrm{~mm}$ in diameter were machined parallel to the rolling direction (RD) from the center, and heat treated in a Bähr DIL 805 A dilatometer to obtain the CCT diagrams of the steels. The samples were heated to $1000{ }^{\circ} \mathrm{C}$ at a heating rate of $10{ }^{\circ} \mathrm{C} / \mathrm{s}$ and held for $15 \mathrm{~min}$, and then cooled to room temperature at cooling rates of $0.5,1,3,5,10,30$ and $50{ }^{\circ} \mathrm{C} / \mathrm{s}$. Vickers microhardness tests of heat-treated specimens were performed on an HVS-1000ZDT Micro-hardness Tester (SIOM, Shanghai, China) with a load of $1 \mathrm{~kg}$ for $15 \mathrm{~s}$, and the average hardness of each sample was determined by making five indentations at $5 \mu \mathrm{m}$ intervals.

Table 1. Chemical composition of the studied steels (wt.\%).

\begin{tabular}{ccccccccccc}
\hline Steel & $\mathbf{C}$ & $\mathbf{S i}$ & $\mathbf{M n}$ & $\mathbf{N i}$ & $\mathbf{C r}+\mathbf{M o}$ & $\mathbf{V}+\mathbf{T i}$ & $\mathbf{B}$ & $\mathbf{S}$ & $\mathbf{P}$ \\
\hline $0.16 \mathrm{C}-0.92 \mathrm{Ni}$ & 0.16 & 0.38 & 1.01 & 0.92 & 1.107 & 0.098 & 0.0015 & 0.0082 & 0.0171 \\
$0.12 \mathrm{C}-1.86 \mathrm{Ni}$ & 0.12 & 0.40 & 1.03 & 1.86 & 1.109 & 0.096 & 0.0014 & 0.0081 & 0.0172 \\
\hline
\end{tabular}

After mechanical grinding and polishing, specimens were etched with $4 \%$ nital for scanning electron microscopy (SEM) observations using a TESCAN MIRA3 LMH (TESCAN, Brno, Czech Republic) field emission scanning electron microscopy (FE-SEM) operating at $10 \mathrm{kV}$. The specimens were electropolished using a solution containing $85 \%$ alcohol, 10\% perchloric acid and 5\% glycerol for electron backscatter diffraction (EBSD) examination. The EBSD analysis was performed with TESCAN MIRA 3 LMH FE-SEM equipped with an Oxford Symmetry EBSD detector (Oxford Instruments, Oxford, United Kingdom) at an acceleration voltage of $20 \mathrm{kV}$, a working distance of $16 \mathrm{~mm}$, tilt angle of $70 \mathrm{deg}$ and a step size of $0.2 \mu \mathrm{m}$. The crystallographic orientation data were post-processed with the CHANNEL 5 software from Oxford-HKL (Oxford Instruments, Oxford, United Kingdom), and the orientation relationship (OR) and grain boundary length was calculated quantitatively using MATLAB ${ }^{\circledR}$ software (MathWorks, Natick, MA, USA).

\section{Results and Discussion}

\subsection{CCT and Vickers Hardness}

The CCT diagrams of the two steels with different C-Ni contents after holding at $100{ }^{\circ} \mathrm{C}$ are shown in Figure 1 . It can be seen that the phase transformation onset temperature of the two steels tended to be about $432^{\circ} \mathrm{C}$ when the cooling rate was greater than $5{ }^{\circ} \mathrm{C} / \mathrm{s}$, which can be regarded as the martensite start transformation temperature (Ms). However, when the cooling rate was decreased, the transformation behavior of the two steels changed significantly. The transformation starting temperature (Ts) of $0.12 \mathrm{C}-1.86 \mathrm{Ni}$ steel was lower than that of $0.16 \mathrm{C}-0.92 \mathrm{Ni}$ steel, especially in the sample cooled at $0.5^{\circ} \mathrm{C} / \mathrm{s}$ where the transformation starting temperature of the former was $483^{\circ} \mathrm{C}$, while that of the latter steel was $525^{\circ} \mathrm{C}$. 


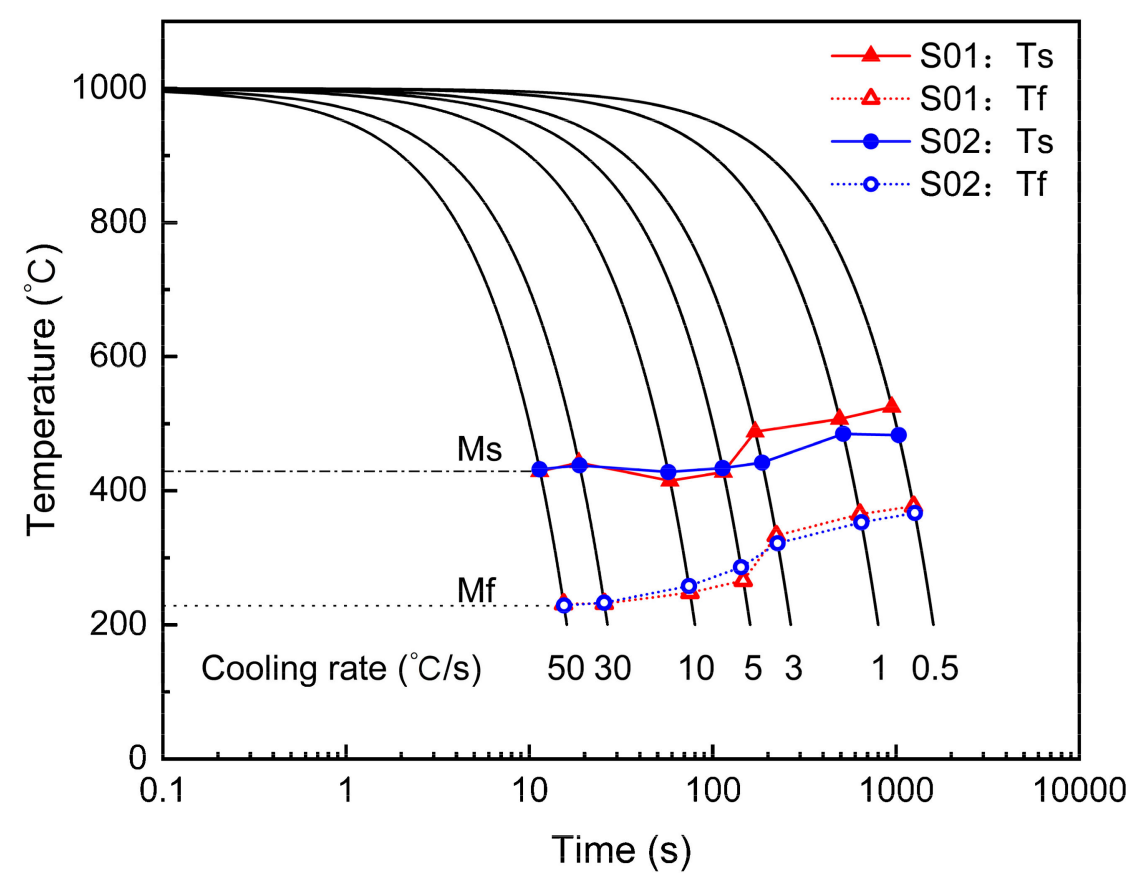

Figure 1. CCT diagrams of two steels at different cooling rates (S01: 0.16C-0.92Ni steel, S02: 0.12C$1.86 \mathrm{Ni}$, Ts/Ms: starting temperature of phase transformation, Tf/Mf: finishing temperature of phase transformation).

The Vickers hardness values of the samples cooled at the rates corresponding to that in the CCT diagram are shown in Table 2. For $0.16 \mathrm{C}-0.92 \mathrm{Ni}$ steel, the hardness decreased by $24 \%$ when the cooling rate was reduced from $50{ }^{\circ} \mathrm{C} / \mathrm{s}$ to $0.5^{\circ} \mathrm{C} / \mathrm{s}$, which means that the hardness at a cooling rate of $0.5{ }^{\circ} \mathrm{C} / \mathrm{s}$ was only $76 \%$ of that at a cooling rate of $50{ }^{\circ} \mathrm{C} / \mathrm{s}$. In contrast, the hardness of $0.12 \mathrm{C}-1.86 \mathrm{Ni}$ steel at low cooling rates was $91 \%$ of that high cooling rates, and the hardness of $0.12 \mathrm{C}-1.86 \mathrm{Ni}$ steel $\left(365.0 \mathrm{HV}_{1}\right)$ was significantly greater than that of $0.16 \mathrm{C}-0.92 \mathrm{Ni}$ steel $\left(333.6 \mathrm{HV}_{1}\right)$ at the lowest cooling rate $\left(0.5^{\circ} \mathrm{C} / \mathrm{s}\right)$. Considering both the phase transformation temperature and hardness, it was concluded that decreasing the C content by $0.04 \%$ and increasing the Ni content by $0.94 \%$ improves the hardenability.

Table 2. Vickers hardness of two steels at different cooling rate $\left(\mathrm{HV}_{1}\right)$.

\begin{tabular}{ccccccccc}
\hline \multirow{2}{*}{ Steel } & \multicolumn{9}{c}{ Cooling Rate $\left({ }^{\circ} \mathbf{C} / \mathbf{s}\right)$} \\
\cline { 2 - 9 } & $\mathbf{0 . 5}$ & $\mathbf{1}$ & $\mathbf{3}$ & $\mathbf{5}$ & $\mathbf{1 0}$ & $\mathbf{3 0}$ & $\mathbf{5 0}$ \\
\hline $0.16 \mathrm{C}-0.92 \mathrm{Ni}$ & 333.6 & 359.4 & 385.8 & 419.6 & 421.2 & 425.6 & 439.4 \\
$0.12 \mathrm{C}-1.86 \mathrm{Ni}$ & 365.0 & 365.6 & 380.8 & 383.0 & 395.0 & 399.8 & 399.4 \\
\hline
\end{tabular}

\subsection{Morphological and Crystallographic Features}

Figure 2 shows the SEM and EBSD results for both steels at a cooling rate of $0.5^{\circ} \mathrm{C} / \mathrm{s}$. The microstructure of $0.16 \mathrm{C}-0.92 \mathrm{Ni}$ steel was mainly characterized by granular bainite, while that of $0.12 \mathrm{C}-1.86 \mathrm{Ni}$ steel exhibited typical lath bainite (Figure $2 \mathrm{a}, \mathrm{b}$ ). In addition, the morphology of M/A changed from block-shaped in 0.16C-0.92Ni steel to film-shaped with a smaller size in $0.12 \mathrm{C}-1.86 \mathrm{Ni}$ steel. The difference in morphology is also well reflected by the fact that the hardenability of $0.12 \mathrm{C}-1.86 \mathrm{Ni}$ steel was higher than that of $0.16 \mathrm{C}-0.92 \mathrm{Ni}$ steel. The low- and high-angle grain boundaries (LAGBs and HAGBs) are highlighted with white $\left(5^{\circ}<\theta<15^{\circ}\right)$, black $\left(15^{\circ}<\theta<45^{\circ}\right)$, or yellow $\left(\theta>45^{\circ}\right)$ lines in band contrast maps (Figure 2c,d). It can be seen that $0.16 \mathrm{C}-0.92 \mathrm{Ni}$ steel has more LAGBs with the distribution of HAGBs in a disordered and irregular pattern, while $0.12 \mathrm{C}-1.86 \mathrm{Ni}$ steel was dominated by HAGBs arranged in parallel, interspersed with a small number of LAGBs, and the density 
of HAGBs of $0.12 \mathrm{C}-1.86 \mathrm{Ni}$ steel was significantly greater than that of $0.16 \mathrm{C}-0.92 \mathrm{Ni}$ steel, especially the HAGBs with $\theta>45^{\circ}$. A quantitative comparison of the grain boundary density is shown in Figure 3. It is shown that the density of the LAGBs and HAGBs is 0.16 and $0.78 \mu \mathrm{m}^{-1}$ for $0.16 \mathrm{C}-0.92 \mathrm{Ni}$ steel, and 0.13 and $1.05 \mu \mathrm{m}^{-1}$ for $0.12 \mathrm{C}-1.86 \mathrm{Ni}$ steel, respectively.

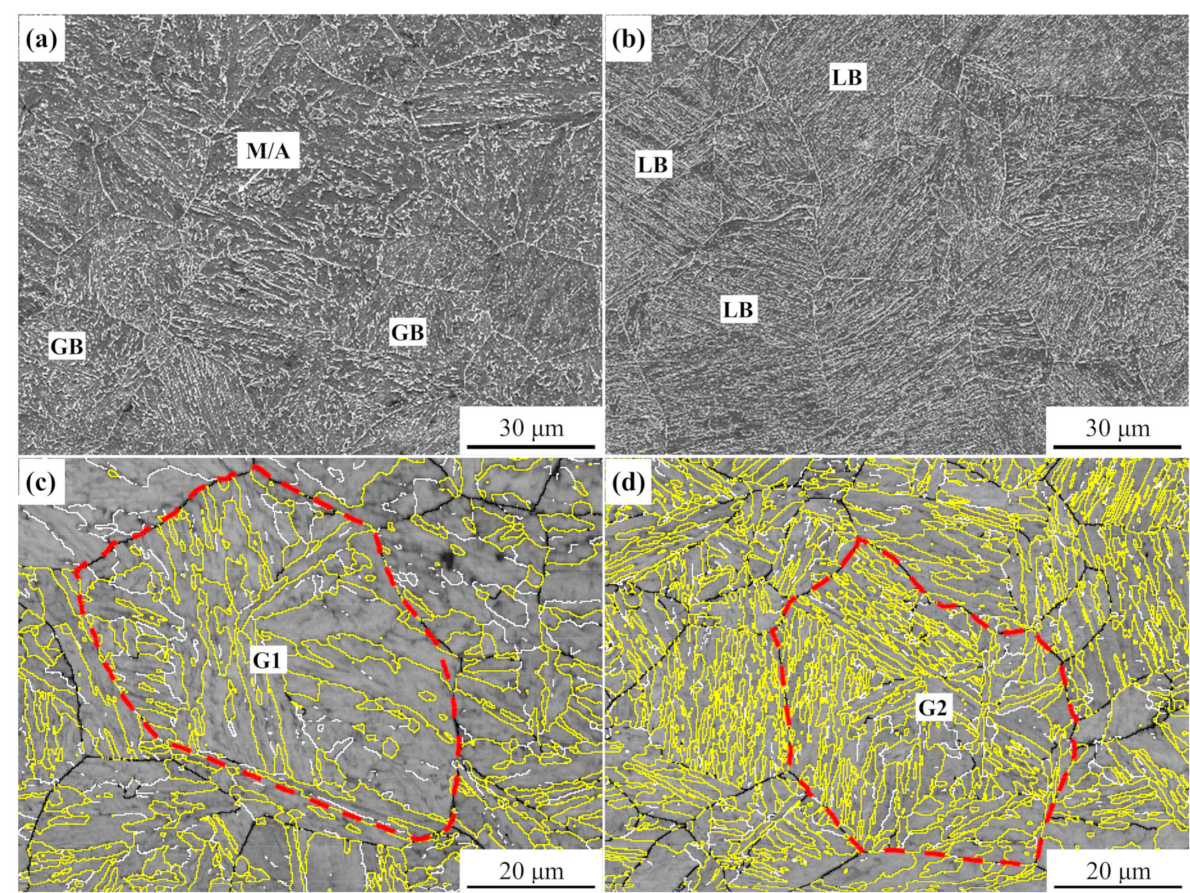

Figure 2. SEM micrographs and band contrast (BC) maps depicting the boundary distribution of two steels cooled at $0.5^{\circ} \mathrm{C} / \mathrm{s}$ : $(\mathbf{a}, \mathbf{c}) 0.16 \mathrm{C}-0.92 \mathrm{Ni}$ steel; (b,d) $0.12 \mathrm{C}-1.86 \mathrm{Ni}$ steel. (GB: granular bainite, LB: lath bainite; G1 and G2: representative grains of two steels; white line: $5^{\circ}<\theta<15^{\circ}$, black line: $15^{\circ}<\theta<45^{\circ}$, yellow line: $\theta>45^{\circ} ; \theta$-misorientation).

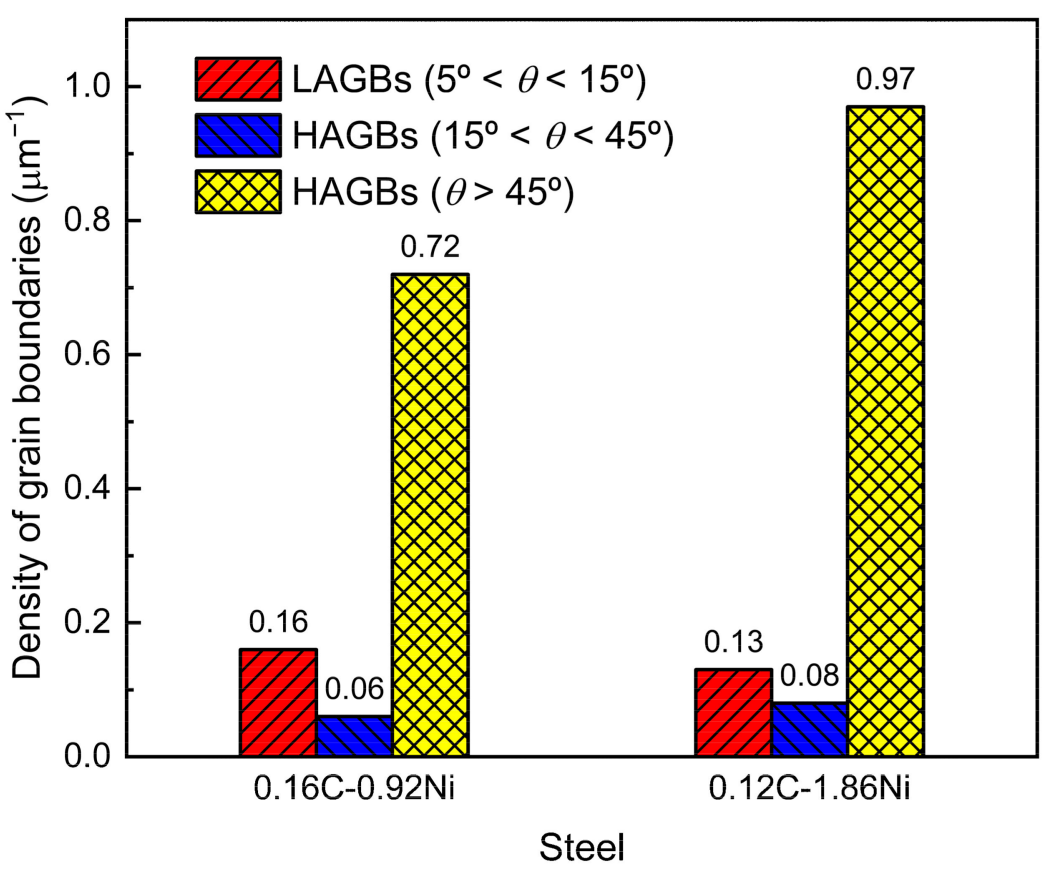

Figure 3. Grain boundary density of two steels at $0.5^{\circ} \mathrm{C} / \mathrm{s}$ cooling rate. 


\subsection{Variant Analysis: Digitization and Visualization}

To clarify the origin of HAGBs in the two steels, a further inspection of the visualization and digitization of the crystallographic features was carried out. Figures 4 and 5 depict the inner structure of representative grains, which are highlighted by red dotted lines in Figure $2 \mathrm{c}, \mathrm{d}$. The different colors in Figure 4 represent different orientations. The boundaries of the block structure in the inverse pole figure (IPF) correspond to the HAGBs, and thus the appearance of the high density of HAGBs is mainly due to the formation of many blocks. In addition, the pole figure (PF) shows that the experimental pole figure (colored graphs) coincides with the theoretical pole figure (black dotted graphs) based on the KurdjumovSachs $(\mathrm{K}-\mathrm{S})$ orientation relationship, indicating that the variants in both G1 and G2 grains maintain a K-S relationship with the prior austenite $[22,23]$.

(a)

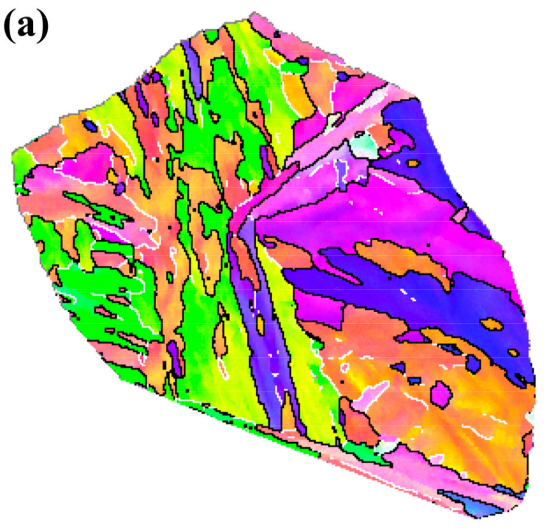

(c)

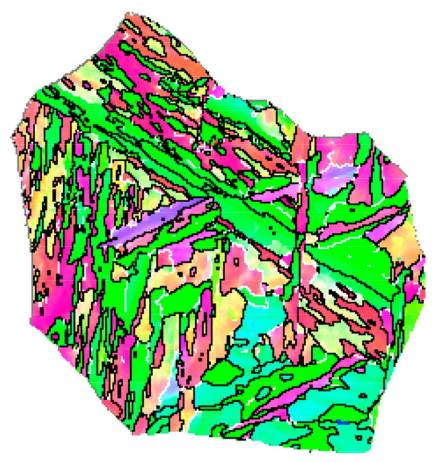

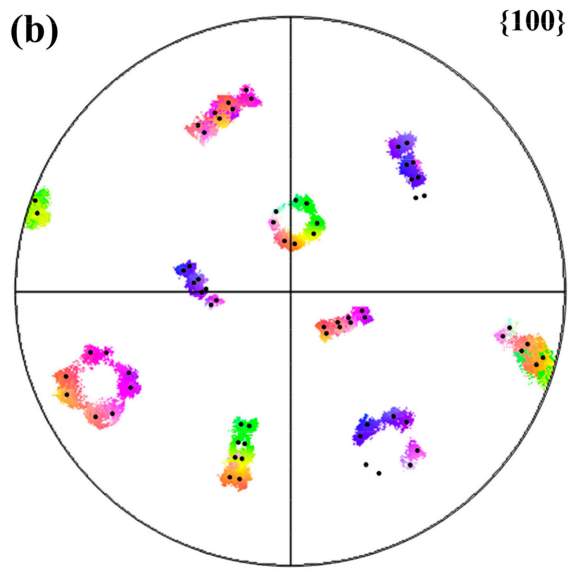

(b)

(d)

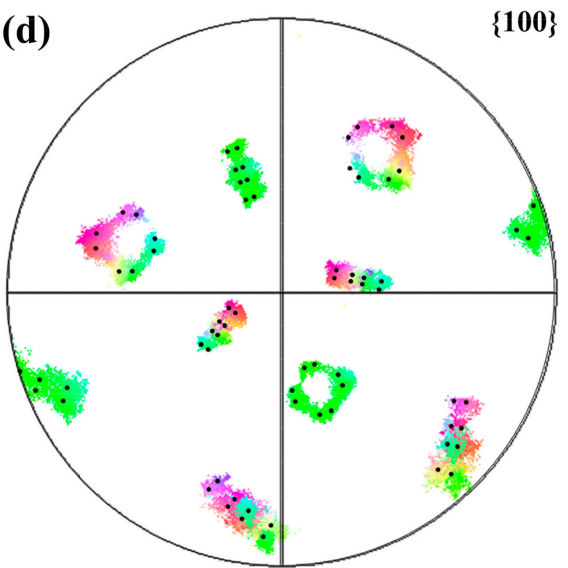

Figure 4. Inverse pole figure (IPF) and pole figure (PF) of representative grains of two steels cooled at $0.5^{\circ} \mathrm{C} / \mathrm{s}$ : $(\mathbf{a}, \mathbf{b}) \mathrm{G} 1$ of $0.16 \mathrm{C}-0.92 \mathrm{Ni}$ steel and (c,d) G2 of $0.12 \mathrm{C}-1.86 \mathrm{Ni}$ steel. (Black dotted graphs: theoretical polar plot based on $\mathrm{K}-\mathrm{S}$ relationship; colored graphs: experimental pole figure).

As seen in the grain boundary maps, the G2 grain of $0.12 \mathrm{C}-1.86 \mathrm{Ni}$ steel exhibited a higher HAGB density $\left(\theta>45^{\circ}\right)$ and a finer structure compared to the G1 grain of $0.16 \mathrm{C}$ $0.92 \mathrm{Ni}$ steel. In general, there are 24 variants in low-carbon steels transformed from a single austenite grain, which can be divided into four CP (closed-packed plane) groups and three Bain groups [24]. The red, yellow and blue colors in the Bain group maps represent Bain1, Bain2 and Bain3, respectively, while the red, yellow, blue and green colors in the $\mathrm{CP}$ group maps represent $\mathrm{CP} 1, \mathrm{CP} 2, \mathrm{CP} 3$ and $\mathrm{CP} 4$, respectively. By combining the GB and Bain maps, it can be found that there were LAGBs between variants belonging to the same Bain group, and HAGBs between those belonging to different Bain groups. Previous studies show that Bain grouping of variants will occur when one Bain region includes 
distinct $\mathrm{CP}$ groups, and $\mathrm{CP}$ grouping of variants will emerge as one $\mathrm{CP}$ region consists of different Bain groups $[20,25,26]$. Hence, the transformation dominated by CP grouping would contribute to a high density of HAGBs. Both G1 and G2 grains were in the form of $\mathrm{CP}$ regions consisting of different Bain groups, but the Bain group width of the G2 grain was much finer. Therefore, the finer Bain groups facilitate the formation of denser HAGBs, which is the reason why the density of HAGBs in $0.12 \mathrm{C}-1.86 \mathrm{Ni}$ steel was higher than that in $0.16 \mathrm{C}-0.92 \mathrm{Ni}$ steel. The structural differences between the two steels are related to the variant selection. A report by Wang et al. suggested that granular bainite formed at a low cooling rate exhibited stronger variant selection in comparison with lath bainite formed at a high cooling rate [10]. Obviously, the variant selection in $0.12 \mathrm{C}-1.86 \mathrm{Ni}$ steel was weaker than that in $0.16 \mathrm{C}-0.92 \mathrm{Ni}$ steel, which promoted the formation of different variants, consistent with the results in [23].

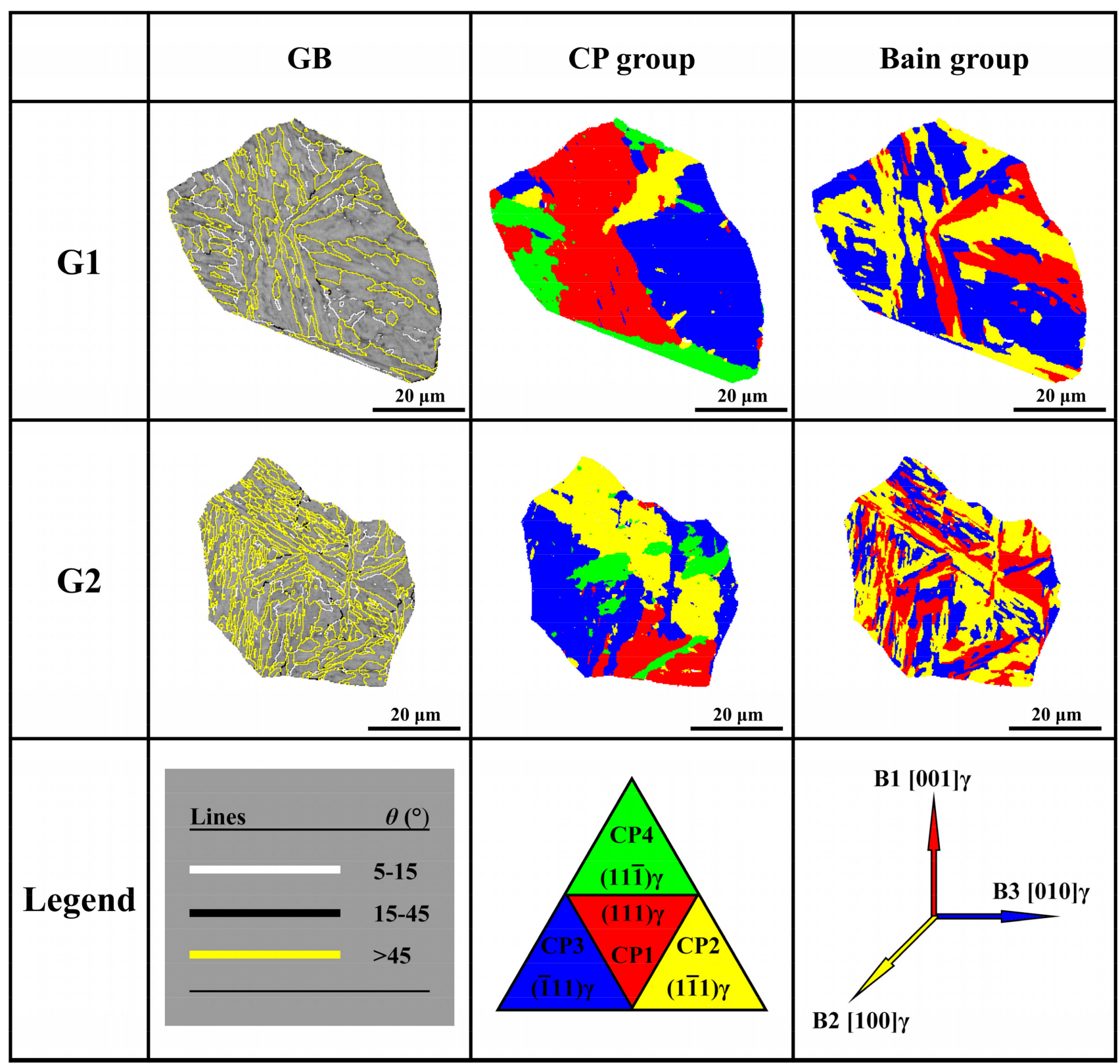

Figure 5. Grain boundary (GB), CP group and Bain group maps depicting the microstructure of representative grains of two steels cooled at $0.5^{\circ} \mathrm{C} / \mathrm{s}$. 
In the austenite to martensite/bainite transformation, 24 variants are generally formed to maintain an approximate $\mathrm{K}-\mathrm{S}$ orientation relationship with the parent austenite phase, and the variant selection affects the orientation, morphology, and mechanical properties of the transformation products [17,25-29]. Thus, it is necessary to analyze the crystallographic information quantitatively to elucidate the effect of lowering $C$ and increasing $\mathrm{Ni}$ on variant selection. According to the crystallographic orientation data collected by EBSD, the average orientation relationship (OR) between parent austenite and product variants for two steels at a cooling rate of $0.5{ }^{\circ} \mathrm{C} / \mathrm{s}$ was calculated through a MATLAB regression program. The mean $\operatorname{OR}(\varphi 1, \Phi, \varphi 2)$ was obtained from the average of the five prior austenite grains, and the actual ORs of the two steels compared with the exact K-S ORs are listed in Table 3. Additionally, in order to clarify the variant pairing rules caused by lowering $C$ and increasing $\mathrm{Ni}$, the rotation angles/axes between V1 and the other variants for the two steels were calculated based on actual OR and Euler angle data from EBSD and summarized in Table 4, as well as the length density of the inter-variant boundaries calculated by this method. The actual OR is inconsistent with the exact K-S OR since there exists accommodation of transformation strain during martensite or bainite transformation [24]. It seems that there was a bigger deviation between the $\mathrm{K}-\mathrm{S}$ OR and the actual OR of those variants within the Bain1 group (i.e., V1/V4, V8, V11, V13, V16, V21 and V24).

Table 3. Orientation relationship (OR) of two steels at $0.5^{\circ} \mathrm{C} / \mathrm{s}$ cooling rate.

\begin{tabular}{ccccc}
\hline \multirow{2}{*}{ OR } & Steel & \multicolumn{3}{c}{ Euler Angle } \\
\cline { 3 - 5 } & & $\boldsymbol{\varphi}_{\mathbf{1}}\left(^{\circ}\right)$ & $\boldsymbol{\Phi}\left(^{\circ}\right)$ & $\boldsymbol{\varphi}_{\mathbf{2}}\left(^{\circ}\right)$ \\
\hline Exact K-S OR & & 114.2 & 10.5 & 204.2 \\
Actual OR & $0.16 \mathrm{C}-0.92 \mathrm{Ni}$ & 120.6 & 8.6 & 195.6 \\
& $0.12 \mathrm{C}-1.86 \mathrm{Ni}$ & 122.3 & 9.3 & 194.2 \\
\hline
\end{tabular}

Table 4. Misorientation axes and angles between V1 and the other variants calculated from the experimentally determined OR (actual OR), and the inter-variant boundary characteristics $[24,30]$.

\begin{tabular}{|c|c|c|c|c|c|c|c|c|}
\hline \multirow{2}{*}{ Variant } & \multirow{2}{*}{ Plane Parallel } & \multirow{2}{*}{ Direction Parallel } & \multicolumn{3}{|c|}{ Rotation Angle/Axis from V1 } & \multirow{2}{*}{$\begin{array}{c}\text { CP } \\
\text { Group }\end{array}$} & \multirow{2}{*}{$\begin{array}{l}\text { Bain } \\
\text { Group }\end{array}$} & \multirow{2}{*}{$\begin{array}{c}\text { Boundary } \\
\text { Type }\end{array}$} \\
\hline & & & Exact K-S OR & $0.16 \mathrm{C}-0.92 \mathrm{Ni}$ & $0.12 \mathrm{C}-1.86 \mathrm{Ni}$ & & & \\
\hline V1 & \multirow{6}{*}{$(111) \gamma / /(011) \alpha$} & {$[-101] \gamma / /[-1-11] \alpha$} & - & - & - & \multirow{6}{*}{$\mathrm{CP} 1$} & B1 & - \\
\hline V2 & & {$[-101] \gamma / /[-11-1] \alpha$} & $60.0^{\circ} /[1,1,-1]$ & $60.3^{\circ}$ & $60.2^{\circ}$ & & B2 & Block \\
\hline V3 & & {$[01-1] \gamma / /[-1-11] \alpha$} & $60.0^{\circ} /[0,1,1]$ & $60.0^{\circ}$ & $60.0^{\circ}$ & & B3 & Block \\
\hline V4 & & {$[01-1] \gamma / /[-11-1] \alpha$} & $10.5^{\circ} /[0,-1,-1]$ & $5.0^{\circ}$ & $5.3^{\circ}$ & & B1 & Sub-block \\
\hline V5 & & {$[1-10] \gamma / /[-1-11] \alpha$} & $60.0^{\circ} /[0,-1,-1]$ & $60.0^{\circ}$ & $60.0^{\circ}$ & & B2 & Block \\
\hline V6 & & {$[1-10] \gamma / /[-11-1] \alpha$} & $49.5^{\circ} /[0,1,1]$ & $55.2^{\circ}$ & $54.7^{\circ}$ & & B3 & Block \\
\hline V7 & \multirow{6}{*}{$(1-11) \gamma / /(011) \alpha$} & {$[10-1] \gamma / /[-1-11] \alpha$} & $49.5^{\circ} /[-1,-1,1]$ & $52.2^{\circ}$ & $50.8^{\circ}$ & \multirow{6}{*}{ CP2 } & B2 & Packet \\
\hline V8 & & {$[10-1] \gamma / /[-11-1] \alpha$} & $10.5^{\circ} /[1,1,-1]$ & $8.9^{\circ}$ & $10.2^{\circ}$ & & B1 & Packet \\
\hline V9 & & {$[-1-10] \gamma / /[-1-11] \alpha$} & $50.5^{\circ} /[-10,3,-13]$ & $53.1^{\circ}$ & $52.5^{\circ}$ & & B3 & Packet \\
\hline V10 & & {$[-1-10] \gamma / /[-11-1] \alpha$} & $50.5^{\circ} /[-7,-5,5]$ & $51.9^{\circ}$ & $51.0^{\circ}$ & & B2 & Packet \\
\hline V11 & & {$[011] \gamma / /[-1-11] \alpha$} & $14.9^{\circ} /[13,5,1]$ & $12.1^{\circ}$ & $13.1^{\circ}$ & & B1 & Packet \\
\hline V12 & & {$[011] \gamma / /[-11-1] \alpha$} & $57.2^{\circ} /[-3,5,6]$ & $57.9^{\circ}$ & $57.7^{\circ}$ & & B3 & Packet \\
\hline V13 & \multirow{6}{*}{$(-111) \gamma / /(011) \alpha$} & {$[0-11] \gamma / /[-1-11] \alpha$} & $14.9^{\circ} /[5,-13,-1]$ & $12.1^{\circ}$ & $13.1^{\circ}$ & \multirow{6}{*}{$\mathrm{CP3}$} & B1 & Packet \\
\hline V14 & & {$[0-11] \gamma / /[-11-1] \alpha$} & $50.5^{\circ} /[-5,5,-7]$ & $51.9^{\circ}$ & $51.0^{\circ}$ & & B3 & Packet \\
\hline V15 & & {$[-10-1] \gamma / /[-1-11] \alpha$} & $57.2^{\circ} /[-6,-2,5]$ & $57.0^{\circ}$ & $56.2^{\circ}$ & & B2 & Packet \\
\hline V16 & & {$[-10-1] \gamma / /[-11-1] \alpha$} & $20.6^{\circ} /[11,-11,-6]$ & $15.1^{\circ}$ & $16.1^{\circ}$ & & B1 & Packet \\
\hline V17 & & {$[110] \gamma / /[-1-11] \alpha$} & $51.7^{\circ} /[-11,6,-11]$ & $51.9^{\circ}$ & $51.4^{\circ}$ & & B3 & Packet \\
\hline V18 & & {$[110] \gamma / /[-11-1] \alpha$} & $47.1^{\circ} /[-24,-10,21]$ & $52.3^{\circ}$ & $51.1^{\circ}$ & & B2 & Packet \\
\hline V19 & \multirow{6}{*}{$(11-1) \gamma / /(011) \alpha$} & {$[-110] \gamma / /[-1-11] \alpha$} & $50.5^{\circ} /[-3,13,10]$ & $53.1^{\circ}$ & $52.5^{\circ}$ & \multirow{6}{*}{$\mathrm{CP} 4$} & B3 & Packet \\
\hline V20 & & {$[-110] \gamma / /[-11-1] \alpha$} & $57.2^{\circ} /[3,6,-5]$ & $57.9^{\circ}$ & $57.7^{\circ}$ & & B2 & Packet \\
\hline V21 & & {$[0-1-1] \gamma / /[-1-11] \alpha$} & $20.6^{\circ} /[3,0,-1]$ & $16.7^{\circ}$ & $18.3^{\circ}$ & & B1 & Packet \\
\hline V22 & & {$[0-1-1] \gamma / /[-11-1] \alpha$} & $47.1^{\circ} /[-10,21,24]$ & $52.3^{\circ}$ & $51.1^{\circ}$ & & B3 & Packet \\
\hline V23 & & {$[101] \gamma / /[-1-11] \alpha$} & $57.2^{\circ} /[-2,-5,-6]$ & $57.0^{\circ}$ & $56.2^{\circ}$ & & B2 & Packet \\
\hline V24 & & {$[101] \gamma / /[-11-1] \alpha$} & $21.1^{\circ} /[9,-4,0]$ & $17.2^{\circ}$ & $18.6^{\circ}$ & & B1 & Packet \\
\hline
\end{tabular}


As listed in Table 4, the inter-variant boundaries from V1/V2-V6 variant pairs belonging to the same CP group are block boundaries, except for the V1/V4 variant pair whose boundary type is a sub-block boundary, while the other inter-variant boundaries are packet boundaries. Figure 6 quantitatively depicts the length density of inter-variant boundaries of the two steels at $0.5^{\circ} \mathrm{C} / \mathrm{s}$ cooling rate. It can be seen that the length density of the V1/V2, V1/V3 (and V5) and V1/V6 variant pairs was significantly higher than that of the other variant pairs, especially the V1/V2 variant pair. The total length density of block boundaries in $0.12 \mathrm{C}-1.86 \mathrm{Ni}$ steel was much higher than that in $0.16 \mathrm{C}-0.92 \mathrm{Ni}$ steel. In addition, the length density of the V1/V2 boundary in $0.12 \mathrm{C}-1.86 \mathrm{Ni}$ steel was significantly higher, and the length density of the V1/V6 boundary was slightly lower compared with $0.16 \mathrm{C}-0.92 \mathrm{Ni}$ steel. Clearly, the difference in the density of block boundaries between the two steels is mainly attributed to the V1/V2 boundary. Previous studies showed that the lower the bainite transformation temperature, the more V1/V2 variant pairs are formed [20,24,26,31]. In this work, the transformation starting temperature of $0.12 \mathrm{C}-1.86 \mathrm{Ni}$ steel was lower than that of $0.16 \mathrm{C}-0.92 \mathrm{Ni}$ steel, resulting in the formation of more V1/V2 variant pairs.

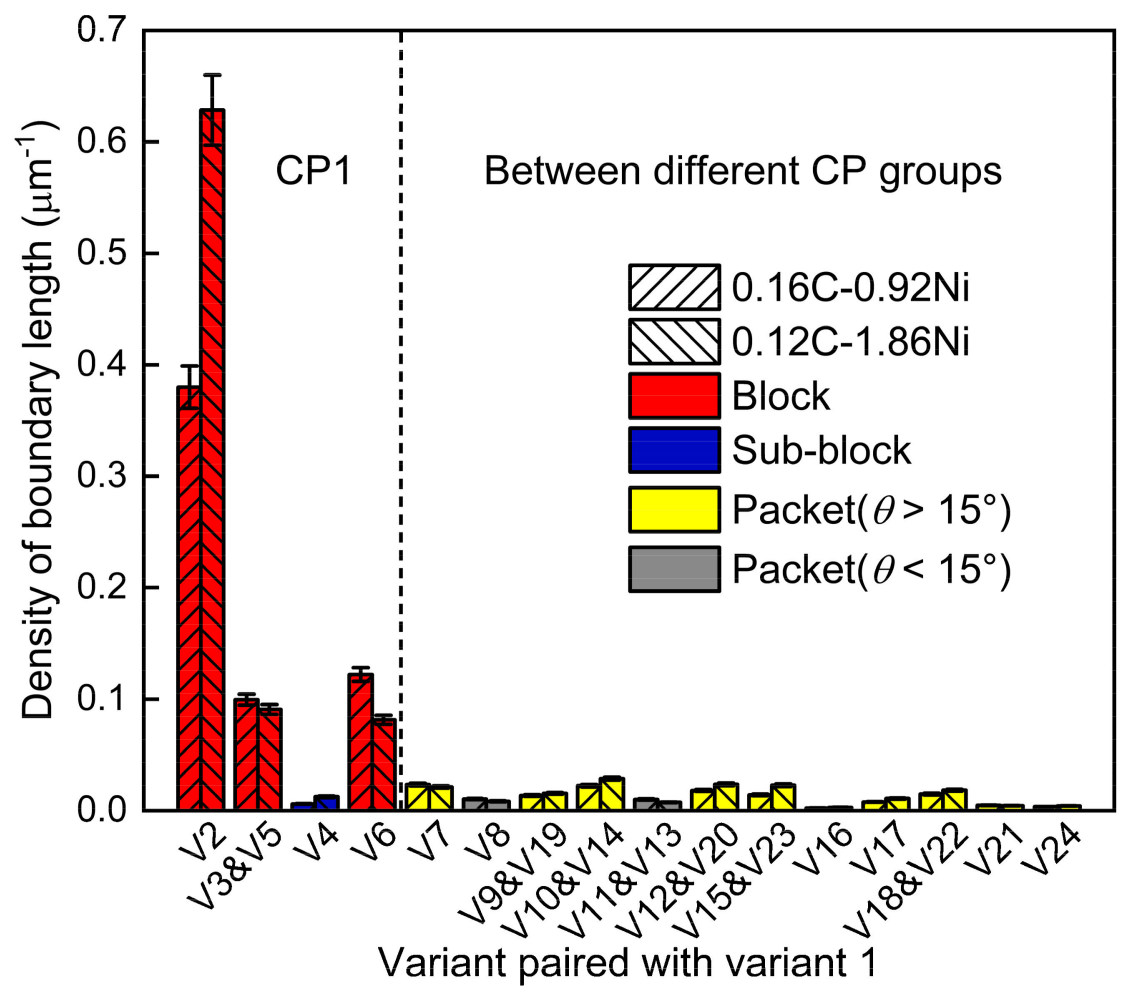

Figure 6. Length density of inter-variant boundaries in two steels cooled at $0.5^{\circ} \mathrm{C} / \mathrm{s}$.

The transformation driving force and self-accommodation of transformation strain determine the variant selection $[23,24,27]$. Since $0.12 \mathrm{C}-1.86 \mathrm{Ni}$ steel has a lower transformation starting temperature than $0.16 \mathrm{C}-0.92 \mathrm{Ni}$ steel, its transformation driving force was higher. In addition, at the lower transformation temperature, the strength of the austenite was higher and thus more self-accommodation was needed. The larger driving forces and more self-accommodation will lead to the refinement of packets and blocks. As a result, the density of block boundaries was higher in $0.12 \mathrm{C}-1.86 \mathrm{Ni}$ steel. Moreover, more V1/V2 variant pairs were formed in $0.12 \mathrm{C}-1.86 \mathrm{Ni}$ steels because they provide the most efficient accommodation of transformation strain at lower temperatures [24,32,33].

\subsection{Correlation of Crystallographic Structure and Hardness}

The inter-variant boundaries were further categorized into block, sub-block and packet boundaries according to the boundary types [24]. The total density of these three crystallographic structures is illustrated in Figure 7, together with the Vickers hardness. Obviously, 
the density of block boundaries in $0.12 \mathrm{C}-1.86 \mathrm{Ni}$ steel was higher compared with that in $0.16 \mathrm{C}-0.92 \mathrm{Ni}$ steel, while the other boundary density did not differ much. It can be seen that hardness is related to the block-boundary density, and high-density block boundaries are beneficial to improve hardness, which is consistent with the results of previous studies $[17,26]$. This also indicates that the difference in hardness between the two steels is due to the density of HAGBs, that is, the higher the density of the HAGBs, the higher the hardness. According to the Hall-Petch relationship [34,35], it is known that the hardness is related to the effective grain size, not only the original austenite grain size, but also its complex internal structure size (e.g., packets, blocks and laths); the finer the effective grain size, the higher the hardness. A higher density of HAGBs means finer effective grain, which contributes to a higher hardness. It is inferred that the phase transformation product with a high density of HAGBs facilitates the increase in hardness.

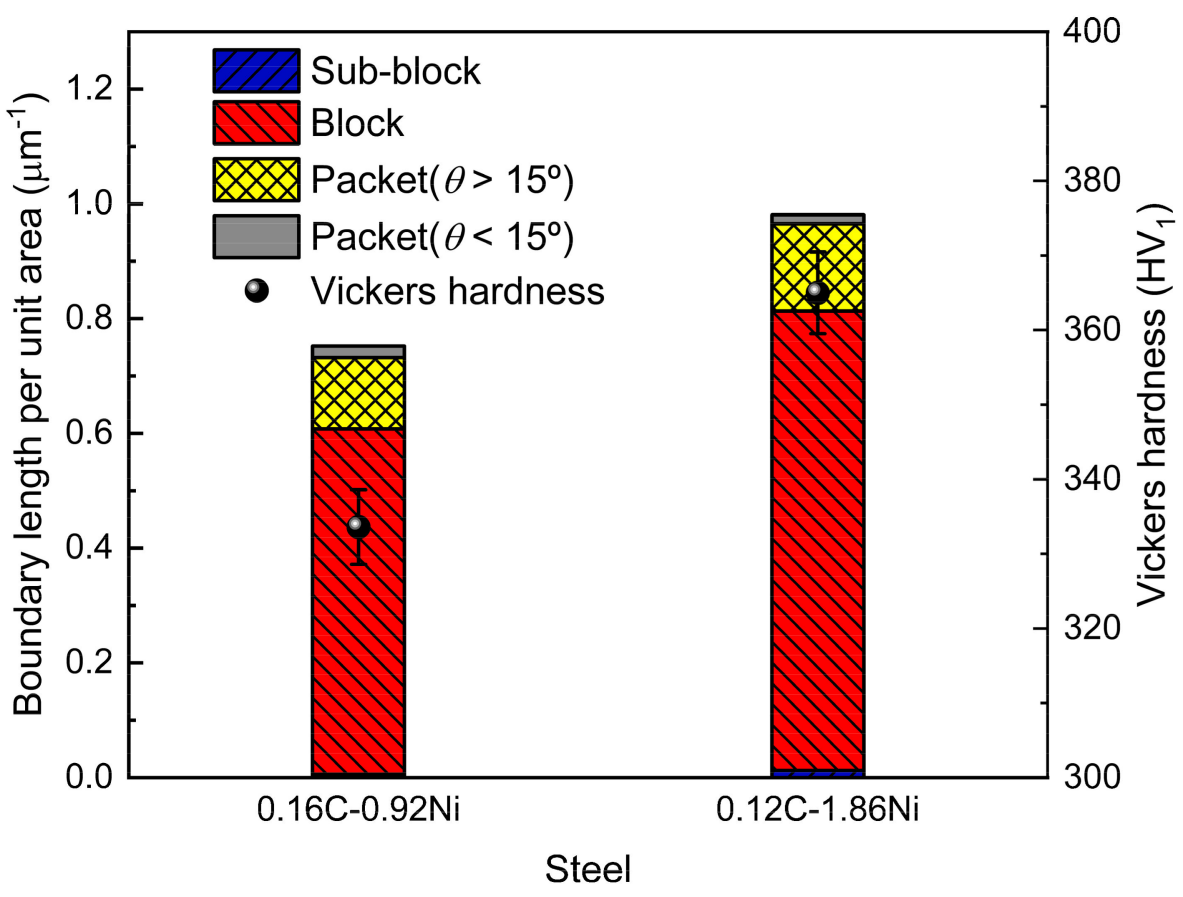

Figure 7. Boundary density and Vickers hardness of the steels cooled at $0.5^{\circ} \mathrm{C} / \mathrm{s}$.

\section{Summary}

Lowering C by $0.04 \%$ and increasing $\mathrm{Ni}$ by $0.94 \%$ ensures the weldability of ultraheavy plates while maintaining high hardenability. The effect of lowering $C$ and increasing $\mathrm{Ni}$ on the microstructure evolution and hardness at low cooling rates was analyzed by characterizing the morphology and crystallography, and the main findings can be summarized as follows.

At a low cooling rate of $0.5^{\circ} \mathrm{C} / \mathrm{s}$, lowering $\mathrm{C}$ and increasing $\mathrm{Ni}$ reduced the bainite transformation temperature. The hardness of $0.12 \mathrm{C}-1.86 \mathrm{Ni}$ steel was higher than that of $0.16 \mathrm{C}-0.92 \mathrm{Ni}$ steel. It was observed that the $0.16 \mathrm{C}-0.92 \mathrm{Ni}$ steel was mainly dominated by granular bainite with a block-shaped $\mathrm{M} / \mathrm{A}$, while $0.12 \mathrm{C}-1.86 \mathrm{Ni}$ steel retained typical lath bainite with a film-shaped $\mathrm{M} / \mathrm{A}$ structure at the low cooling rate. Although both steels exhibited the $\mathrm{CP}$ group containing different Bain groups, the $0.12 \mathrm{C}-1.86 \mathrm{Ni}$ steel has more and finer Bain groups compared with the $0.16 \mathrm{C}-0.92 \mathrm{Ni}$ steel. In addition, the density of the V1/V2 boundary in the $0.12 \mathrm{C}-1.86 \mathrm{Ni}$ steel was significantly higher. By lowering $\mathrm{C}$ and increasing $\mathrm{Ni}$, the steel has smaller packets and blocks, higher density of block boundaries, and more V1/V2 variant pairs, which enhances the hardness at low cooling rates. 


\begin{abstract}
Author Contributions: Conceptualization, Z.L. and Y.Y.; methodology, J.Y.; software, Z.W.; validation, Z.L., Y.Y. and J.Y.; formal analysis, Z.L. and Y.Y.; investigation, J.Y.; resources, H.G.; data curation, Z.L. and J.Y.; writing—original draft preparation, Z.L.; writing—review and editing, Y.Y. and H.G.; visualization, Z.L.; supervision, H.G.; project administration, H.G. and C.S.; funding acquisition, H.G. and C.S. All authors have read and agreed to the published version of the manuscript.
\end{abstract}

Funding: This research was funded by the Key Research and Development Program of Shandong Province, China (No. 2019JZZY020238) and the National Natural Science Foundation of China (No. 51371001).

Institutional Review Board Statement: Not applicable.

Informed Consent Statement: Not applicable.

Data Availability Statement: Data are contained within the article.

Acknowledgments: The authors sincerely thank Yaohui Jin for providing materials in this study.

Conflicts of Interest: The authors declare no conflict of interest.

\title{
References
}

1. Xie, Z.J.; Fang, Y.P.; Han, G.; Guo, H.; Misra, R.D.K.; Shang, C.J. Structure-property relationship in a 960 MPa grade ultrahigh strength low carbon niobium-vanadium microalloyed steel: The significance of high frequency induction tempering. Mater. Sci. Eng. A 2014, 618, 112-117. [CrossRef]

2. Yu, Y.S.; Hu, B.; Gao, M.L.; Xie, Z.J.; Rong, X.Q.; Han, G.; Guo, H.; Shang, C.J. Determining role of heterogeneous microstructure in lowering yield ratio and enhancing impact toughness in high-strength low-alloy steel. Int. J. Miner. Metall. Mater. 2021, 28, 816-825. [CrossRef]

3. Capdevila, C.; García-Mateo, C.; Chao, J.; Caballero, F.G. Advanced vanadium alloyed steel for heavy product applications. Mater. Sci. Technol. 2009, 25, 1383-1386. [CrossRef]

4. An, F.C.; Zhao, S.X.; Xue, X.K.; Wang, J.J.; Yuan, G.; Liu, C.M. Incompleteness of bainite transformation in quenched and tempered steel under continuous cooling conditions. J. Mater. Res. Technol. 2020, 9, 8985-8996. [CrossRef]

5. Pan, T.; Wang, X.; Su, H.; Yang, C. Effect of alloying element Al on hardenability and mechanical properties of micro-B treated ultra-heavy plate steels. Acta Metall. Sin. 2014, 50, 431-438. [CrossRef]

6. Zhou, T.; Yu, H.; Wang, S.Y. Microstructural characterization and mechanical properties across thickness of ultra-heavy steel plate. Steel Res. Int. 2017, 88, 1700132. [CrossRef]

7. Al Hajeri, K.F.; Garcia, C.I.; Hua, M.; Deardo, A.J. Particle-stimulated nucleation of ferrite in heavy steel sections. ISIJ Int. 2006, 46, 1233-1240. [CrossRef]

8. Li, W.; Cao, R.; Zhu, W.; Guo, X.; Jiang, Y.; Chen, J. Microstructure evolution and impact toughness variation for high strength steel multi-pass weld metals with various cooling rates. J. Manuf. Processes 2021, 65, 245-257. [CrossRef]

9. Kong, X.; Lan, L. Optimization of mechanical properties of low carbon bainitic steel using TMCP and accelerated cooling. Procedia Eng. 2014, 81, 114-119. [CrossRef]

10. Wang, X.L.; Wang, Z.Q.; Dong, L.L.; Shang, C.J.; Ma, X.P.; Subramanian, S.V. New insights into the mechanism of cooling rate on the impact toughness of coarse grained heat affected zone from the aspect of variant selection. Mater. Sci. Eng. A 2017, 704, 448-458. [CrossRef]

11. Wang, X.L.; Ma, X.P.; Wang, Z.Q.; Subramanian, S.V.; Xie, Z.J.; Shang, C.J.; Li, X.C. Carbon microalloying effect of base material on variant selection in coarse grained heat affected zone of X80 pipeline steel. Mater. Charact. 2019, 149, 26-33. [CrossRef]

12. Asahi, H. Effects of Mo addition and austenitizing temperature on hardenability of low alloy B-added steels. ISIJ Int. 2002, 42, 1150-1155. [CrossRef]

13. Hara, T.; Asahi, H.; Uemori, R.; Tamehiro, H. Role of combined addition of niobium and boron and of molybdenum and boron on hardnenability in low carbon steels. ISIJ Int. 2004, 44, 1431-1440. [CrossRef]

14. Han, F.; Hwang, B.; Suh, D.W.; Wang, Z.; Lee, D.L.; Kim, S.J. Effect of molybdenum and chromium on hardenability of low-carbon boron-added steels. Met. Mater. Int. 2008, 14, 667-672. [CrossRef]

15. Li, Y.J.; Ponge, D.; Choi, P.; Raabe, D. Atomic scale investigation of non-equilibrium segregation of boron in a quenched Mo-free martensitic steel. Ultramicroscopy 2015, 159, 240-247. [CrossRef]

16. Takahashi, J.; Ishikawa, K.; Kawakami, K.; Fujioka, M.; Kubota, N. Atomic-scale study on segregation behavior at austenite grain boundaries in boron- and molybdenum-added steels. Acta Mater. 2017, 133, 41-54. [CrossRef]

17. Huang, S.; Wu, B.B.; Wang, Z.Q.; Yu, Y.S.; Wang, C.S.; Yan, L.; Li, X.C.; Shang, C.J.; Misra, R.D.K. EBSD study on the significance of carbon content on hardenability. Mater. Lett. 2019, 254, 412-414. [CrossRef]

18. Dossett, J.L.; Totten, G.E. ASM Handbook Volume 4A: Steel Heat Treating Fundamentals and Processes; ASM International: Materials Park, OI, USA, 2013.

19. Chung, Y.D.; Fujii, H.; Ueji, R.; Tsuji, N. Friction stir welding of high carbon steel with excellent toughness and ductility. Scripta Mater. 2010, 63, 223-226. [CrossRef] 
20. Huang, S.; Yu, Y.S.; Wang, Z.Q.; Su, S.; Chen, K.; Yuan, S.F.; Xie, Z.J.; Shang, C.J. Crystallographic insights into the role of nickel on hardenability of wear-resistant steels. Mater. Lett. 2022, 306, 130961. [CrossRef]

21. Huang, G.; Wan, X.; Wu, K.; Zhao, H.; Misra, R.D. Effects of small Ni addition on the microstructure and toughness of coarsegrained heat-affected zone of high-strength low-alloy steel. Metals 2018, 8, 718. [CrossRef]

22. Miyamoto, G.; Hori, R.; Poorganji, B.; Furuhara, T. Crystallographic analysis of proeutectoid ferrite/austenite interface and interphase precipitation of vanadium carbide in medium-carbon steel. Metall. Mater. Trans. A 2013, 44, 3436-3443. [CrossRef]

23. Kawata, H.; Sakamoto, K.; Moritani, T.; Morito, S.; Furuhara, T.; Maki, T. Crystallography of ausformed upper bainite structure in Fe-9Ni-C alloys. Mater. Sci. Eng. A 2006, 438-440, 140-144. [CrossRef]

24. Takayama, N.; Miyamoto, G.; Furuhara, T. Effects of transformation temperature on variant pairing of bainitic ferrite in low carbon steel. Acta Mater. 2012, 60, 2387-2396. [CrossRef]

25. Yu, Y.-S.; Wang, Z.-Q.; Wu, B.-B.; Zhao, J.-X.; Wang, X.-L.; Guo, H.; Shang, C.-J. Tailoring variant pairing to enhance impact toughness in high-strength low-alloy steels via trace carbon addition. Acta Metall. Sin. (Engl. Lett.) 2021, 34, 755-764. [CrossRef]

26. Yu, Y.S.; Wang, Z.Q.; Wu, B.B.; Rong, X.Q.; Wei, L.J.; Yuan, S.F.; Guo, H.; Shang, C.J. New insight into the hardenability of high strength low alloy steel from the perspective of crystallography. Mater. Lett. 2021, 292, 129624. [CrossRef]

27. Furuhara, T.; Chiba, T.; Kaneshita, T.; Wu, H.; Miyamoto, G. Crystallography and interphase boundary of martensite and bainite in steels. Metall. Mater. Trans. A 2017, 48, 2739-2752. [CrossRef]

28. Miyamoto, G.; Iwata, N.; Takayama, N.; Furuhara, T. Variant selection of lath martensite and bainite transformation in low carbon steel by ausforming. J. Alloys Compd. 2013, 577, S528-S532. [CrossRef]

29. Chiba, T.; Miyamoto, G.; Furuhara, T. Comparison of variant selection between lenticular and lath martensite transformed from deformed austenite. ISIJ Int. 2013, 53, 915-919. [CrossRef]

30. Morito, S.; Tanaka, H.; Konishi, R.; Furuhara, T.; Maki, T. The morphology and crystallography of lath martensite in Fe-C alloys. Acta Mater. 2003, 51, 1789-1799. [CrossRef]

31. Wu, B.B.; Wang, Z.Q.; Yu, Y.S.; Wang, X.L.; Shang, C.J.; Misra, R.D.K. Thermodynamic basis of twin-related variant pair in high strength low alloy steel. Scripta Mater. 2019, 170, 43-47. [CrossRef]

32. Filippov, S.A.; Zolotorevsky, N.Y. Orientation relationship and variant pairing in bainite of low carbon steels depending on thermomechanical treatment. Mater. Lett. 2018, 214, 130-133. [CrossRef]

33. Lambert-Perlade, A.; Gourgues, A.F.; Pineau, A. Austenite to bainite phase transformation in the heat-affected zone of a high strength low alloy steel. Acta Mater. 2004, 52, 2337-2348. [CrossRef]

34. Morris, J.W.; Lee, C.S.; Guo, Z. The nature and consequences of coherent transformations in steel. ISIJ Int. 2003, 43, 410-419. [CrossRef]

35. Guo, Z.; Lee, C.S.; Morris, J.W. On coherent transformations in steel. Acta Mater. 2004, 52, 5511-5518. [CrossRef] 